\title{
A question of (audience) reach
}

\section{Emma Weitkamp}

Abstract

Keywords
Taking the International Science in Popular Culture conference as a starting point, this editorial considers audiences for cultural products, considering the size of audiences (from blockbuster films, to intimate science slams), their pre-existing (or lack of pre-existing) interest in the subject and what this might offer the field of science communication.

Popularization of science and technology; Representations of science and technology

Sitting in the conference hall during the International Science in Popular Culture conference, held at Alpen Adria Universität, Klagenfurt, in Austria I was struck by the huge difference in reach, or scale, of the different media and projects discussed. One of the first speakers started by contrasting the audiences of popular Hollywood films, such as The Day After Tomorrow, with documentaries focusing on climate change. These documentaries not only have much smaller audiences, but the audiences themselves are likely to support the view of the documentary maker in relation to climate change; that is climate change documentaries with environmental viewpoints will be watched by those who already believe in climate change, while those promoting sceptical views are likely to be viewed predominantly by those holding sceptical views already. This is consistent with communication theories that postulate that we, as audiences, seek out media and messages that are consonant with our existing views and thereby reinforce existing views and behaviours, for example cognitive dissonance theory proposed by Leon Festinger which suggests that we shy away from experiences that promote inconsistencies with our existing beliefs. It is also a premise underlying internet technologies that present us with 'information' (also advertising) based on the searches and websites we access.

A key appeal of blockbuster films and popular television programmes is their potential to reach beyond the usual suspects (to bring unexpected or unsought information and views to our attention). For example, Lowe et al. [2006] in a study of U.K. filmgoers who had seen The Day After Tomorrow, found that only 5\% were primarily motivated to see the film for environmental reasons. David Kirby of Manchester University noted in his Keynote address, 'Scientists on the silver screen: scientists influence on cinema, cinema's influence on science', that many Hollywood filmmakers work with consultant scientists to ensure at least a modicum of scientific accuracy. He argues that we are now in a 'Golden Age' of science in popular culture, as high budget and high grossing films and TV 
programmes, such as The Theory of Everything and The Big Bang Theory, demonstrate 'that science-based popular cultural products can be both critically acclaimed and financially successful'. Kirby argues that scientists (and some science funding agencies) see popular culture as both an opportunity to stimulate popular interest and knowledge about science, and a threat to public understanding (e.g. if the science is incorrect). Science in fictional films, then has the potential to reach wide audiences. However, filmgoers can only choose from those films that actually get produced and as Alexa Weik von Mossner, of Alpen Adria Universität, Austria, in her talk 'The good, the bad, and the terrifying: depictions of climate change in popular film', highlighted, there seems to be a remarkable lack of popular films focusing on climate change, with The Day After Tomorrow standing out as one of few such films.

There is also the question of how audiences interpret science in fictional contexts. Lowe et al. [2006] question whether 'audiences accept scientifically mediated science fiction as science fact' (p. 452) and conclude that 'Overall, the film [The Day After Tomorrow], like government policy, sends mixed messages and, although it can be said to have sensitized viewers and perhaps motivated them to act on climate change, the individuals who participated in this study do not feel they have access to information on what action they can take or the opportunity in their daily lives to individually or collectively implement change.' (p. 453)

Climate science does seem to be popular with documentary film makers, though these films reach much smaller audiences. von Mossner explored the rhetorical strategies used in these documentaries and argues that they are often designed to stimulate intellectual and emotional engagement possibly with a view to changing behaviour or encouraging action. Not surprisingly, the framing of these documentaries means that they appeal to selected audiences, as von Mossner argues, they 'preach to the choir'. Howell's [2011] study of audiences for the documentary The Age of Stupid, supports this view; she found that 'the filmgoers surveyed were a very particular group, not representative of the general public. They exhibited very high levels of concern about climate change and motivation to act to mitigate it, even before seeing the film.' (p. 185). She argues that The Age of Stupid seeks to encourage behaviour change (to pro-environmental behaviours) by presenting a disaster scenario, but one which could still be avoided. In her audience surveys, she found increased concern and motivation to act immediately after the film, but these heightened levels of concern and motivation to act did not persist in the long term [Howell, 2014] and the behaviours viewers reported changing tended to be ones that were easy to achieve and low cost.

Still smaller audiences can be expected at face to face events. My own paper on science theatre, explored audiences for two performance pieces, Bloodlines and The Chaos Cabaret, while Miira Hill, of Technische Universität Berlin, Germany discussed Science Slams. As genres, these events might have fairly wide reach, but an individual performance is necessarily limited by the size of the venue, though Hill pointed out that in some cases, the YouTube videos produced of the slam performances can attract larger audiences. She cites Giulia Enders, Darm mit Charme performance which has nearly half a million views on YouTube and resulted in a bestselling book 'Gut: The Inside Story of Our Body's Most Underrated Organ'. 
The self-selecting nature of audiences, whether to documentary or face to face events has received wide attention in the literature (for example, McCallie et al. [2009], explore the many audiences for science events; Bultitude and Sardo [2012] explore the motivations of participants and informal science events; and more generally Livingstone [2006] discusses audiences for cultural events), and finding ways to reach those without a pre-existing interest in the topic remains a challenge. The notion that TV or blockbuster films will open science up to new audiences may be one reason that there seems to be increasing interest in science in popular culture. Even so, there is little research exploring the impact of these cultural products on viewers, whether already interested or otherwise. Those studies that have been conducted acknowledge the sophisticated readings audiences make of popular cultural products, meaning that science communication through popular culture is far from well understood or straightforward. As the International Conference on Science in Popular Culture discussed, there remains a need for research to understand the opportunities and effects of different types of cultural products on people's engagement with science and the scientific issues of the day. Perhaps these media will be able to reach beyond the choir and present science in contexts that are accessed by a range of people. With the move amongst many large media organisations to develop tools and algorithms that narrowcast information, presenting you only with material that meets your existing interests, we need mechanisms that will reach beyond the usual suspects enabling wide sections of society to comment on, engage with or at least learn about many different sciences.

Bultitude, K. and Sardo, M. (2012). 'Leisure and Pleasure: Science Events in Unusual Locations'. International Journal of Science Education 34 (18), pp. 2775-2795.

Enders, G. (2015). Gut: The Inside Story of Our Body's Most Underrated Organ. Vancouver, Canada: Greystone Books.

Howell, R. A. (2011). ‘Lights, Camera ... Action? Altered attitudes and behaviour in response to the climate change film The Age of Stupid'. Global Environmental Change 21 (1), pp. 177-187.

- (2014). 'Investigating the long-term impacts of climate change communications on individual attitudes and behaviour'. Environment and Behaviour 46 (1), pp. 70-101.

Livingstone, S. (2006). Audiences and Publics: when cultural engagement matters in the public sphere. Bristol, U.K.: Intellect Books.

Lowe, T., Brown, K., Dessai, S., de França Doria, M., Haynes, K. and Vincent, K. (2006). 'Does tomorrow ever come? Disaster narrative and public perceptions of climate change'. Public Understanding of Science 15, pp. 435-457.

McCallie, E., Bell, L., Lohwater, T., Falk, J. H., Lehr, J. L., Lewenstein, B. V., Needham, C. and Wiehe, B. (2009). Many Experts, Many Audiences: Public engagement with science and informal science education. CAISE Inquiry Group Report. Washington, DC, U.S.A.: CAISE. 
Dr. Emma Weitkamp is an Associate Professor in Science Communication at the University of the West of England, Bristol where she teaches on an MSc in Science Communication and provides training in science communication for practitioners and Ph.D. students. Emma is also Editor in Chief of JCOM.

E-mail: Emma.Weitkamp@uwe.ac.uk.

Weitkamp, E. (2015). 'A question of (audience) reach'. JCOM 14 (03), E. 